\title{
sciendo
}

\section{The Employer Branding Creation and HR Marketing in Selected Healthcare Service Providers}

\author{
Jiř́́ BEJTKOVSKÝ \\ Tomas Bata University in Zlín, Faculty of Management and Economics, Department \\ of Management and Marketing, Mostní 5139, Zlín, Czech Republic \\ bejtkovsky@utb.cz \\ Narcis COPCA \\ Bucharest University of Economic Studies, Bucharest, Romania \\ narciscopca@yahoo.com
}

\begin{abstract}
The paper focuses on the employer branding creation and HR marketing in selected healthcare service providers. The employer branding creation and HR marketing have become an interesting and creative area both in the field of HR management and marketing. The process of the employer branding creation and the conception of HR marketing coming from within the organizations and corporations could an interesting and effective tool that management not only in healthcare service providers could use to create a relationship with their current and also the potential employees. The aim of the article was to find out, among other things, which factors influence the choice of the employer (concerning the selected healthcare service provider). This study was researched on the gender and biological age of the respondents. For research purposes, a structured questionnaire was used. This questionnaire was distributed among selected healthcare service providers in the Czech Republic. The proposed research hypotheses have been verified through research. The statistical method of the Pearson's Chi-square test was chosen to verify the research hypotheses. This research study has brought the compelling findings. Firstly, that there is a statistically significant relationship between the factors influencing the choice of the employer (the selected healthcare service provider) and the age of the respondents, and secondly that there is a statistically significant relationship between the factors influencing the choice of the employer and the gender of the respondents in selected healthcare service providers in the Czech Republic.
\end{abstract}

Keywords: employer branding creation, HR marketing, healthcare service providers, human resource management, employees, Czech Republic.

Please cite the article as follows: Bejtkovský, J., Copca, N. (2020), "The Employer Branding Creation and HR Marketing in Selected Healthcare Service Providers", Management \& Marketing. Challenges for the Knowledge Society, Vol. 15, No. 1, pp. 95-108. DOI: 10.2478/mmcks-2020-0006.

\section{Introduction}

The issue of the employer branding creation and HR marketing is a current topic discussed in connection with the lack of human resources. Nowadays, qualified human resources have a choice of employer. As an employer, the management of each corporation should be able to effectively and purposefully work not only with its brand but also with the tools and variables of internal and external HR marketing (Bondarouk and Ruël, 2009; Edwards and Edwards, 2013; Strenitzerová, 2016). 
The research gap that can also be observed in literature is related to the lack of information and research in connection with the employer branding creation and HR marketing in the healthcare service providers. In the analysis of secondary information sources, both foreign and domestic, no direct reference to the issue of the employer branding creation and HR marketing was found. These two areas are examined differently. The author's perspective and innovation in this area is in the interconnection of the two areas. Another research gap in literature is in the implementation of employer branding creation and HR marketing in the field of healthcare service providers. These facts should not be perceived only as a research gap, but also as an opportunity and a challenge for further research.

Nowadays, a lack of skilled, experienced and motivated human resources is a major personnel or business issue for the most of domestic and foreign corporations (firms, institutions, organizations, enterprises, offices, and companies). Both employer branding creation and HR marketing can importantly help in these cases. The process of the employer branding creation can attract an attention of a potential employee and HR marketing tools can be used for other activities related to the recruitment process in the company.

The concept of employer branding creation and the concept of HR marketing have been created as an employment strategy and as a solution of problem of a shortage of human resources in the labor market not only in the Czech Republic.

According to Arriscado et al. (2019); Dincă, Dima and Rózsa (2019), to reach these goals, corporations are supposed to have a particular image and a strong brand of employers and management of corporation need to know how to communicate with current and potential human resources. Moreover, the research contracts with the business environment should be increased (Dima and Ghinea, 2016).

In this context, Kietzmann and Canhoto (2013) claim that corporations have always informed of what their human resources think and say about their corporation.

The opinions of the human resource form not only the engagement, loyalty, retention and the satisfaction of current human resources, but also the manner of how the corporations are perceived by other people and their ability to attract new employees. As Alnıaçık et al. (2014) note, the process of attracting and retaining skilled, experienced and motivated human resources is a significant issue for corporations in all scales around the world. There is an important role played by the employer branding and HR marketing. Verma and Ahmad (2016) claim that management of corporations perceives the significance of HR marketing and employer branding in attracting, stimulating, motivating, engaging and retaining talent.

Therefore, the research in this field should further focus on identifying specific factors that influence the choice of the employer and whether there is a relationship between the biological age or gender of the potential employees. The findings can be beneficial in the area of human resources management not only for healthcare service providers.

The uniqueness and the benefit of the paper are based on the revelation of factors influencing the choice of the employer (the selected healthcare service provider). These examined factors were designed in the context of the employer branding and HR marketing tools. The research paper consists of the following parts: (1) the literature review - this section deals with terms such as employer branding and then HR marketing, (2) the methodology - this section contains and describes the main aim of this paper, the research methods and hypotheses, (3) the introduction of the research results and discussion, (4) the conclusion - this section concludes the main findings of the research. 


\section{Literature review}

Constant competition and a profit focus urge corporation to strive for the best performance at the low cost, with qualified and loyal employees (Oláh et al., 2017).

According to Elving et al. (2012), the corporations need highly loyal human resources in order to fulfill the wishes and needs of their stakeholders and achieve success. On the other hand, the academia should partner with business environment for meeting the requirements of the labour market (Dima, et al., 2017). The concept of the employer branding creation and HR marketing could be a powerful tool for attracting human resources with high potential.

The literature review focuses on the definition of four basic areas, namely (a) the employer branding, (b) HR marketing, (c) the factors influencing the choice of employer and (d) Healthcare in the Czech Republic. These four pillars are presented on the basis of their logical continuity.

The employer branding can be targeted, effectively and positively disseminated, supported and strengthened in the labor market by means of HR marketing (internal and external HR marketing) tools.

According to Radford (2009), the employer branding is significant for the HR marketing concept. The employer branding defines the personality of the corporation as the preferred employer.

\section{The employer branding}

Bondarouk and Ruël (2009) assert that employer branding is a popular research topic in various studies. The employer branding creation is a well-known concept but its specification is not available yet.

In this context, Wroblowská (2019) says that the well-known employer brand is becoming more and more important factor of success in the global competitive environment across different segments.

Nevertheless, according to Backhaus and Tikoo (2004), the brand of employer is the application of branding rules to human resources management and relationships between human resources (employees) and corporations (employers).

Jain and Bhatt (2015) say that the certain importance of employer branding factors differs in particular across biological age and gender of prospective human resources working in the corporation.

The employer branding creation provides a concrete perception of the employment situation in the corporation, for the purpose of doing attraction or retention of the skilled, experienced and motivated employees (Dooley et al., 2007; Sullivan, 2004).

Mandhanya and Maitri (2010) claim that the concept of employer branding builds an image of the employer on the labor market, but also the principles, activities, procedures, actions and policies of the corporation.

Barrow and Mosley (2011) say that employer branding characterize corporation's reputation and name as an employer and its perception, values, behavior towards to its human resources.

Wilden et al. (2010) perceive the term employer branding as a set of functional, psychological and economic options or benefits that are associated with work in a particular corporation. These associations are created by potential employees who could work in such corporation. The knowledge of these associations is necessary and essential for creating a 
competitive and attractive brand of an employer. Regarding this, Dabirian et al. (2017) understand employer branding as the advantages provided by employment and associated with a specific employing corporation.

According to Minchington (2006), the quality of employer branding can pay off for the corporation for example in the form of faster recruitment, in its lower cost, or can increase involvement of current human resources.

The process of the employer branding creation serves to build a better awareness of the corporation in the labor market and also helps HR marketing in the area of authenticity and relationship with its current and potential human resources (Plchová and Turáková, 2016).

\section{HR marketing}

According to Ng et al. (2010), Saini et al. (2014), a concept of HR marketing can be defined or perceived as the application of marketing principles and rules in the area of human capital management. Aggerholm et al. (2011) understand the concept of HR marketing as a tool for managing, building, and influencing human resources relationships in a corporation.

Edwards and Edwards (2013) claim that concept of HR marketing is an influence on external and internal environment of a corporation. HR marketing is not just about an image, history, name, logo, provided products or offered services to customers but also about the human resources. For example, employees are very important in providing banking products and services (Dima and Vasilache, 2009).

Regarding this, Ng et al. (2010), Saini et al. (2014) say that the concept of HR marketing is related to terms such as brand, image or reputation of an employer, human capital management, the labor market, and the overall business, staff, and marketing strategy of the corporation.

Grabara (2013) say that if concept of HR marketing is to create and develop a quality brand of the employer, it must present only real and truthful facts and information for current or potential employees.

HR marketing is therefore a broad concept because it focuses on two large groups of people. According to Hitka et al. (2015) or Love and Singh (2011), the concept of HR marketing focuses and creates suitable and good conditions for the work of current employees working in the corporation. Its main goal is to effectively stimulate and motivate current human resources to keep them in the corporation for as long as possible. According to Archana et al. (2014) or Woźniak (2015), the concept of HR marketing focuses on potential human resources with a goal to attract their attention and stimulate and motivate them to work in a particular corporation. Without a doubt, besides HR marketing tools, the employer branding is also important.

$\mathrm{Ng}$ et al. (2010) or Saini et al. (2014) perceive the opportunities and positive aspects of the HR marketing concept in (a) strengthening the competitiveness, image, reputation and brand of the corporation, (b) in the lower time and financial aspects of the corporate recruitment process, (c) and in greater job satisfaction, motivation and engagement of human resources in the corporation. Urbancová and Hudáková (2017) argue that the benefits and positive impacts of the HR marketing concept can be measured. These characteristics can be identified by quantitative variables (especially socio-economic and economic indicators) and described through qualitative variables. The qualitative 
information and data are based on the behavior, attitudes, and feelings of employees of the corporation.

Thus, the management of the corporation should investigate what factors influence the choice of the employer for different groups of people (current and potential human resources) in order to be able to work effectively with all HR marketing variables (Saini and Jawahar, 2019).

\section{The factors influencing the choice of the employer}

It can be said that there are various factors influencing the choice of the employer. For example, Saini and Jawahar (2019) say that the employment experience of existing employees, corporate image and corporate name influence the recommendations for choice of the employer.

In this context, Chitu et al. (2014) present that job stability, stimulating wage conditions, employee benefits, brand, image, reputation and name of the corporation, good opportunities for career growth or possibilities for further training of employees are currently most common criteria for choice of the employer.

According to Athanasou (2003), the factors influencing the choice of the employer can be divided into the following groups such as the specific size of the occupation, the proportion of human resources working full-time, wage conditions, earnings and employee benefits, opportunities for career growth and job prospects, gender dominance in an occupation, reputation of the corporation, working conditions, the level of unemployment in the occupation and the predominant age group in the job.

Among the significant factors influencing the choice of the employer can be included corporation's reputation, image or brand of the corporation, market position, size of the corporation, relations within the corporation, the salary and employee benefits, working with modern equipment and technologies and possibilities of personal development within the corporation (Gogolová et al., 2015).

However, Dutta and Punnose (2010) mention that there are differences due to gender, age, region, educational and parental background in relation to choosing not only the first job.

\section{Healthcare in the Czech Republic}

The Czech Republic is centrally located in the heart of Europe. The Czech Republic has a democratic parliamentary system of government and a well-developed economy. The Czech Republic has been a member of the Organization for Economic Co-operation and Development since December 1995, a member of the North Atlantic Treaty Organization since February 1999 and a member of the European Union since May 2004. The healthcare system in the Czech Republic underwent and still is undergoing dramatic changes since the Velvet revolution in 1989: (a) the implementation between 2005 and 2006 of a new risk adjustment scheme for redistributing social health insurance contributions among the health insurance funds; (b) the introduction in 2008 of user fees for doctor visits, hospital stays, prescription pharmaceuticals e.g., and out-of-pocket payments; (c) the inclusion in 2008 of the State Institute for Drug Control in the process of setting maximum prices for pharmaceuticals for transparency of price settings; (d) the introduction in 2008 of a programme to supply accredited providers with additional financial support for training nurses and physicians; (e) an initiative to improve the quality of highly specialized care by 
identifying high performing healthcare facilities and allowing for special contractual conditions between these facilities and the health insurance funds (Kinkorová and Topolčan, 2012).

Healthcare in the Czech Republic is decentralized and market-oriented in comparison with the systems of other European countries. The founders of healthcare organizations are various subjects of the state administration - the Ministry (in the case of the University hospital), regions and municipalities. Private healthcare organizations are also being developed. The system is financed through compulsory health insurance (Björnberg, 2017).

According to Mihályi (2000), the Czech health system is based on five pillars: (a) solidarity; (b) high degree of self-administration; (c) multisource financing with major share of public health insurance; (d) equal availability of healthcare for all insured persons and (e) obligatory vaccination against infectious diseases.

According to the Euro Health Consumer Quality Index in Europe, Czech Healthcare is ranked 13th in 2016, behind Sweden and two ahead of the UK (Björnberg, 2017).

\section{Research hypotheses development}

The goal of the paper was to find out which factors influence the choice of the employer - the selected healthcare service provider. This research study was investigated on the basis of the biological age and the gender of the respondents. For research purposes, two research hypotheses have been defined. These research hypotheses have been defined on the basis of a literature review and in confrontation with realized secondary researches.

Dutta and Punnose (2010) say that there are relationships and differences between age and employer choice.

H1: There is a statistically significant relationship between the factors influencing the choice of the employer and the age of the respondents in selected healthcare service providers in the Czech Republic.

Athanasou (2003); Urbancová and Hudáková (2017) claim that gender affects the choice of employer and is very closely related to it.

$\mathrm{H} 2$ : There is a statistically significant relationship between the factors influencing the choice of the employer and the gender of the respondents in selected healthcare service providers in the Czech Republic.

It can be said that there are various factors influencing the awareness and the choice of the employer. It is therefore appropriate and beneficial to investigate these factors and their relationships in detail.

\section{Methodology}

The research article deals with human capital management more precisely the employer branding creation and HR marketing in selected healthcare service providers in the Czech Republic. This research topic is up-to-date and often discussed.

The main goal of this submitted paper was to find out which factors influence the choice of the employer in context of employer branding creation and HR marketing in selected healthcare service providers. This research study was investigated on the basis of the gender and biological age of the respondents, and was performed among employees of the selected healthcare service providers in the Czech Republic.

The secondary sources of information have been analyzed by scientific journals, scientific papers and scientific monographs from Scopus database and Web of Science 
database. These monographs, journals and articles were focused on the employer branding creation and HR marketing. The primary sources of information were obtained through a quantitative and qualitative marketing research, which uses a questionnaire survey as a technique for collecting research data and information. Some research results are introduced in this paper. Based on an exploratory research, a literary research, a synthesis of the data and information and the sub-chapter of research hypotheses development, two research hypotheses (H1 and H2) have been created. Namely, these are the following hypotheses:

Dutta and Punnose (2010) say that there are relationships and differences between age and employer choice.

$\mathrm{H} 1$ : There is a statistically significant relationship between the factors influencing the choice of the employer and the biological age of the respondents in selected healthcare service providers in the Czech Republic.

Athanasou (2003); Urbancová and Hudáková (2017) claim that gender affects the choice of employer and is very closely related to it.

$\mathrm{H} 2$ : There is a statistically significant relationship between the factors influencing the choice of the employer and the gender of the respondents in selected healthcare service providers in the Czech Republic.

The questionnaire survey was implemented by using the method of quantitative research. The purpose of this sampling method was to reach a large number of respondents compared to qualitative research. The questionnaire survey is generally a high-quality marketing tool for effective identification and collection of various types of data, information and opinions. The standardized questionnaire survey was distributed in both printed and electronic versions. The standardized questionnaire survey contained eighteen questions. The questions were (1) open, (2) semi-open and of course (3) closed. At the end of the standardized questionnaire survey, the identification questions were given to respondents. The questionnaire survey had respect for anonymity of respondents and the ethical aspect.

According to Fernández-Monroy, Martín-Santana and Galván-Sánchez Inmaculada (2018), the use of the questionnaire survey limits the approach to information gathering although its application in research studies or research papers may be deemed suitable.

Another limit may be that there are not many scientific and research works related to this topic, so a precise comparison of the results cannot be made.

The small research sample of respondents can also be perceived as the limit of the questionnaire survey (respondents working at the selected healthcare service providers).

Selected healthcare service providers have been included in a research study on the basis of earlier research cooperation. The questionnaire was further tested (a pretest was conducted in the second quarter of 2017). Eleven respondents participated in this pretest. After the pretest of the questionnaire survey, a main research followed. The main research was conducted from the fourth quarter of 2017 until the second half of 2018.

Altogether, eight hundred and thirty-nine questionnaires were obtained. Due to the incompleteness of some questionnaires, eleven questionnaires had to be rejected. Thus, the final research file consisted of eight hundred and twenty-eight questionnaires. This research sample served to verify the stated research hypotheses. The absolute and relative frequencies (the tools of the descriptive statistics) were applied in the analysis of the obtained data and information. 
The verification of the $\mathrm{H} 1$ hypothesis and $\mathrm{H} 2$ hypothesis was realized by the Pearson's statistical method of the Chi-square test. A principle of this test is based on the measurement of dependencies. The Chi-square test determines whether there is relationship between the statistical variables. It can be said that the existence of given values of the $\mathrm{X}$ signifies the probability of occurrence of certain Y characters. The zero hypothesis is not accepted, if $p$ value is lower than a typical level of significance (0.05 it means $5 \%$ ). A software program Microsoft Excel 2013 and a statistical software IBM SPSS Statistics 23 were used to evaluate the obtained data.

\section{Results and discussions}

Based on a literature review that focuses on employer branding creation and HR marketing, two research hypotheses ( $\mathrm{H} 1$ and $\mathrm{H} 2$ ) have been formulated. The suggested research hypotheses were verified using Pearson's chi-square test. As part of this verification, Microsoft Excel 2013 and IBM SPSS Statistics 23 were used.

The structure of the addressed employees working in selected healthcare service providers in the Czech Republic are presented in table (Table 1).

Table 1. The structure of the addressed employees working in selected healthcare service providers in the Czech Republic

\begin{tabular}{|c|c|c|c|}
\hline Variable & Category & $\begin{array}{l}\text { The absolute } \\
\text { frequency (n) }\end{array}$ & $\begin{array}{c}\text { The relative } \\
\text { frequency }(\%)\end{array}$ \\
\hline \multirow{3}{*}{ Gender } & Female & 479 & 57.85 \\
\hline & Male & 349 & 42.15 \\
\hline & Total & 828 & 100.00 \\
\hline \multirow{7}{*}{$\begin{array}{c}\text { Biological age (Age } \\
\text { interval) }\end{array}$} & up to 20 years & 20 & 2.42 \\
\hline & $21-30$ years & 171 & 20.65 \\
\hline & $31-40$ years & 278 & 33.58 \\
\hline & $41-50$ years & 249 & 30.07 \\
\hline & $51-60$ years & 92 & 11.11 \\
\hline & 61 years and over & 18 & 2.17 \\
\hline & Total & 828 & 100.00 \\
\hline \multirow{5}{*}{$\begin{array}{l}\text { Employees in } \\
\text { healthcare by } \\
\text { category }\end{array}$} & Doctors (Medical employees) & 168 & 20.29 \\
\hline & Nurses and assistants & 220 & 26.57 \\
\hline & Other non-medical employees & 254 & 30.68 \\
\hline & Non-health employees & 186 & 22.46 \\
\hline & Total & 828 & 100.00 \\
\hline
\end{tabular}

Source: Authors' own research.

Among the factors influencing the choice of the employer (the selected healthcare service provider in the Czech Republic) were included the following variables: (1) brand, image and name of the healthcare service providers, (2) employee benefits and advantages, (3) flexible working conditions (internships, work-life balance), (4) good opportunities for career growth, (5) location and size of the healthcare service providers, (6) possibilities and support (further) training of employees, (7) stimulating wage conditions, and (8) working with modern equipment and technologies. The list of the factors influencing the choice of the employer was formed on a literature review and the following authors and researchers: Athanasou (2003); Dutta and Punnose (2010); Gogolová et al. (2015); Chitu et al. (2014); Saini and Jawahar (2019). 
H1: There is a statistically significant relationship between the factors influencing the choice of the employer and the age of the respondents in selected healthcare service providers in the Czech Republic.

H0: There is no correlation between the factors influencing the choice of the employer and the age of the respondents.

The data characterizing the $\mathrm{H} 1$ hypothesis are presented in the table (Table 2).

Table 2. The verification of the H1 hypothesis by means of the Pearson's Chi-square test

H1: There is a statistically significant relationship between the factors influencing the choice of the employer and the biological age of the respondents in selected healthcare service providers in the

\begin{tabular}{|c|c|c|c|c|c|c|c|}
\hline $\begin{array}{c}\text { The factors } \\
\text { influencing the } \\
\text { choice of the } \\
\text { employer }\end{array}$ & Chi-square & $\mathbf{d f}$ & $\mathbf{p}$-value & $\begin{array}{c}\text { The factors } \\
\text { influencing the } \\
\text { choice of the } \\
\text { employer }\end{array}$ & Chi-square & $\mathbf{d f}$ & p-value \\
\hline $\begin{array}{c}\text { Brand, image and } \\
\text { name of the } \\
\text { healthcare service } \\
\text { providers }\end{array}$ & 69.240 & 5 & 0.000 & $\begin{array}{c}\text { Location and size } \\
\text { of the healthcare } \\
\text { service providers }\end{array}$ & 62.620 & 5 & 0.000 \\
\hline $\begin{array}{c}\text { Employee benefits } \\
\text { and advantages }\end{array}$ & 90.575 & 5 & 0.000 & $\begin{array}{c}\text { Possibilities and } \\
\text { support further) } \\
\text { training of employees }\end{array}$ & 50.179 & 5 & 0.000 \\
\hline $\begin{array}{c}\text { Flexible working } \\
\text { conditions } \\
\text { (internships, work-life } \\
\text { balance) }\end{array}$ & 174.020 & 5 & 0.000 & $\begin{array}{c}\text { Stimulating wage } \\
\text { conditions }\end{array}$ & 34.765 & 5 & 0.000 \\
\hline $\begin{array}{c}\text { Good opportunities } \\
\text { for career growth }\end{array}$ & 375.827 & 5 & 0.000 & $\begin{array}{c}\text { Working with modern } \\
\text { equipment and } \\
\text { technologies }\end{array}$ & 19.398 & 5 & 0.002 \\
\hline
\end{tabular}

Source: Authors' own research, own processing at SPSS Statistics program 23.

The above-mentioned $\mathrm{H} 1$ hypothesis was divided into individual sub-sections according to the factors influencing the choice of the employer (the selected healthcare service provider in the Czech Republic). Results of the research hypothesis (H1) verification show that he p-value of Pearson's Chi-square test of independence is lower than the defined level of significance (5\%) for each the factors influencing a choice of the employer. Thus, the result of a verification of the $\mathrm{H} 1$ hypothesis presents discovery that the $\mathrm{H} 0$ hypothesis of independence was therefore rejected at a level of an independence of $5 \%$. The $\mathrm{H} 1$ hypothesis was not rejected.

The H1 hypothesis - there is a statistically significant relationship between the factors influencing the choice of the employer and the biological age of the respondents in selected healthcare service providers in the Czech Republic - was therefore confirmed.

$\mathrm{H} 2$ : There is a statistically significant relationship between the factors influencing the choice of the employer and the gender of the respondents in selected healthcare service providers in the Czech Republic.

H0: There is no correlation between the factors influencing the choice of the employer and the gender of the respondents.

The data characterizing the $\mathrm{H} 2$ hypothesis are presented in the table (Table 3). 
Table 3. The verification of the H2 hypothesis by means of the Pearson's Chi-square test

\begin{tabular}{|c|c|c|c|c|c|c|c|}
\hline \multicolumn{8}{|c|}{$\begin{array}{l}\text { H2: There is a statistically significant relation between the factors influencing the choice of the } \\
\text { employer and the gender of the respondents in selected healthcare service providers in the Czech } \\
\text { Republic. }\end{array}$} \\
\hline $\begin{array}{l}\text { The factors } \\
\text { influencing the } \\
\text { choice of the } \\
\text { employer }\end{array}$ & Chi-square & df & p-value & $\begin{array}{l}\text { The factors } \\
\text { influencing the } \\
\text { choice of the } \\
\text { employer }\end{array}$ & Chi-square & df & p-value \\
\hline $\begin{array}{l}\text { Brand, image and } \\
\text { name of the } \\
\text { healthcare service } \\
\text { providers }\end{array}$ & 33.055 & 1 & 0.000 & $\begin{array}{l}\text { Location and size } \\
\text { of the healthcare } \\
\text { service providers }\end{array}$ & 94.233 & 1 & 0.000 \\
\hline $\begin{array}{l}\text { Employee benefits } \\
\text { and advantages }\end{array}$ & 10.883 & 1 & 0.000 & $\begin{array}{l}\text { Possibilities and } \\
\text { support (further) } \\
\text { training of employees }\end{array}$ & 10.343 & 1 & 0.000 \\
\hline $\begin{array}{c}\text { Flexible working } \\
\text { conditions } \\
\text { (internships, work-life } \\
\text { balance) } \\
\end{array}$ & 4.921 & 1 & 0.002 & $\begin{array}{l}\text { Stimulating wage } \\
\text { conditions }\end{array}$ & 4.832 & 1 & 0.022 \\
\hline $\begin{array}{l}\text { Good opportunities } \\
\text { for career growth }\end{array}$ & 10.411 & 1 & 0.001 & $\begin{array}{l}\text { Working with modern } \\
\text { equipment and } \\
\text { technologies }\end{array}$ & 5.531 & 1 & 0.019 \\
\hline
\end{tabular}

Source: Authors' own research, own processing at SPSS Statistics program 23.

The H2 hypothesis was also divided into individual sub-sections according to the factors influencing the choice of the employer (the selected healthcare service provider in the Czech Republic). The discovered results of the research hypothesis (H2) verification show that he p-value of Pearson's Chi-square test of independence is lower than the defined level of significance (5\%) for each the factors influencing the choice of the employer. Thus, the result of the verification of the $\mathrm{H} 2$ hypothesis shows discovery that the $\mathrm{H} 0$ hypothesis of independence was therefore rejected at a level of an independence of 0.05 . The $\mathrm{H} 2$ hypothesis was therefore not rejected.

The H2 hypothesis - there is a statistically significant relation between the factors influencing the choice of the employer and the gender of the respondents in selected healthcare service providers in the Czech Republic - was therefore confirmed.

Due to the absence of sufficient research data and information related to the employer branding creation and HR marketing at healthcare service providers, the discussion has a general character. Thus, the discussion could not be directly debated with the research results. However, the discussion presents data and conclusions from similar researches.

The fact that gender is, among other things, closely linked to employer branding, confirms the results of the research studies by Urbancová and Hudáková (2017). Urbancová and Hudáková (2017) defined in their research studies five main benefits and strengths resulting from brand of employer, a key part being played by human resources themselves. These are the benefits and strengths: (1) attracting new experienced human resources, (2) retaining important human resources, (3) increasing motivation of the human resources, (4) improving public awareness of a corporation brand, and (5) improving financial indicators. They further came up with the finding that size, gender structure and ownership 
of the corporations can impact the advantages, strengths and benefits resulting from employer branding. The brand of the employer has advantages in good HR process 0.697 to $0.756)$, procedure of public brand to the consumers and good employer and creates a profit (0.692 to 0.865$)$.

The research finding that the brand, image and name of the corporation have an influence on the choice of employer also supports research from Sokro (2012). His research study says that employer brand has a major effect the choice of the corporation and also the choice of human resources to stay or leave the corporation. Suikkanen (2010) reports the findings of his researches in which he found that employer branding can be considered as a method of human resource retention as it impacts the entire employment experience, improves the concept of a work place and decreases voluntary turnover. In this context, Martin et al. (2011) state the findings of their research study that brand of the employer unites components of human resource management, marketing, and corporate communication and thus, multi-functional cooperation is considered fundamental.

According to research findings from Aggerholm et al. (2011), it can be said that an efficient and successful HR marketing and employer branding requires a constant monitoring and analysis of changes in the corporate environment (external and internal environment). If this condition is met, HR marketing and employer branding can be implemented well in the corporate practice. Based on the research studies of Jenkins (2009) or Saxena and Jain (2012), it can be said that the effective use of HR marketing along with the employer branding creation can be an important tool for the strategic management of human capital.

\section{Conclusion}

This research paper deals with selected factors influencing the choice of the employer. These factors were based on a literature review and were examined in selected healthcare service providers in the Czech Republic. The factors influencing the choice of the employer are related to the field of HR marketing tools and employer branding.

The major aim of this submitted article was to find out which factors influence the choice of the employer in context of employer branding creation and HR marketing in selected healthcare service providers. This study was researched on the gender and biological age of the respondents and it was performed among employees of the selected healthcare service providers in the Czech Republic. For research purpose, eight variables were determined.

The research results presented in the conclusions are that there is a statistically significant relationship between the factors influencing the choice of the employer (the selected healthcare service provider in the Czech Republic) and the biological age and the gender of the respondents.

There is very little research on the use of HR marketing tools and employer branding in the healthcare service providers in the Czech Republic. A novelty and value of this research paper consists in examining and subsequently discovering factors that have a significant impact on the choice of employer in the context of biological age and gender of the respondents working at the selected healthcare service provider in the Czech Republic. The findings of the study thus offer new theoretical and practical knowledge in a field where research lags far behind practice. 
The data suggest that the limits of a research study can be seen in a small sample of the addressed respondents (respondents working at the selected healthcare service providers) or the respondents were only employees working in the Czech Republic. Therefore, for further research studies, it would be suitable to extend the research sample in order to generalize the results.

\section{References}

Aggerholm, H. K., Andersen, S. E., \& Thomsen, C. (2011). Conceptualising employer branding in sustainable organisations, Corporate Communications. An International Journal, 16(02), 105-123.

Alnıaçık, E., Alnıaçık, Ü., Erat, S., \& Akçin, K. (2014). Attracting Talented Employees to the Company: Do We Need Different Employer Branding Strategies in Different Cultures? In 10th International Strategic Management Conference, Procedia - Social and Behavioral Sciences, 150(01), 336-344.

Archana, L., Nivya, V. G., \& Thankam, S. M. (2014). Recruitment through social media area: Human Resource. Journal of Business and Management, 01(01), 37-41.

Arriscado P., Quesado H., \& Sousa B. (2019). Employer Branding in the Digital Era Attracting and Retaining Millennials Using Digital Media. In Túñez-López M., Martínez-

Fernández VA., López-García X., Rúas-Araújo X., Campos-Freire F. (eds)

Communication: Innovation \& Quality. Studies in Systems, Decision and Control, vol. 154. Springer, Cham, pp. 391-403.

Athanasou, J. (2003). Factors Influencing Job Choice. International Journal for Educational and Vocational Guidance, 03(03), 205-221.

Backhaus, K., \& Tikoo, S. (2004). Conceptualizing and Researching Employer Branding. Career Development International, 09(05), 501-517.

Barrow, S., \& Mosley, R. (2011). The employer brand: Bringing the best of brand management to people at work. Hoboken, NJ: John Wiley \& Sons.

Björnberg, A. (2017). Health Consumer Powerhouse. Euro Health Consumer Index 2016. Report. 1st edition. Health Consumer Powerhouse. ISBN 978-91-980687-5-7.

Bondarouk, T., \& Ruël, H. J. M. (2009). Electronic Human Resource Management: challenges in the digital era. The International Journal of Human Resource Management, 20(03), 505-514. DOI: $10.1080 / 09585190802707235$.

Dabirian, A., Kietzmann, J., \& Diba, H. (2017). A great place to work!? Understanding crowdsourced employer branding. Business Horizons, 60(02), 197-205.

Dima, A.M. and Ghinea, V.M. (2016) A Model of Academic Leadership. Proceedings of the 12th European Conference on Management, Leadership and Governance, ECMLG 2016, Edited by Florina Pînzaru and Constantin Brătianu, published by Academic Conferences and Publishing International Limited, Reading, UK, pp.61-70.

Dima, A.M., Hadad, S., Luchian, I. (2017). Review on the dimensions of business-university alliances. Proceedings of the 11th International Conference on Business Excellence, pp. 64-73. DOI: 10.1515/picbe-2017-0007.

Dima, A. M., \& Vasilache, S. (2009). ANN Model for Corporate Credit Risk Assessment. In 2009 International Conference on Information and Financial Engineering, Singapore, pp. 94-98. DOI: 10.1109/ICIFE.2009.33.

Dincă, V. M., Dima, A. M., \& Rózsa, Z. (2019). Determinants of cloud computing adoption by Romanian SMEs in the digital economy. Journal of Business Economics and Management, 20(04), 798-820. DOI: doi.org/10.3846/jbem.2019.9856.

Dooley, R., Levine, D., \& Russell, A. (2007). Branding, Trends, Communicable Diseases. HR Magazine, 52(12), 31-32.

Dutta, A., \& Punnose, E. M. (2010). Factors Affecting Choice of First Employer: A Study of Indian Management Graduates. Global Business Review, 11(03), 435-448. 
Edwards, M. R., \& Edwards, T. (2013). Employee responses to changing aspects of the employer brand following a multinational acquisition: a longitudinal study. Human Resource Management, 52(01), 27-54.

Elving, W. J. L, Westhoff, J. J. C., Meeusen, K., \& Schoonderbeek, J. W. (2012). The war for talent? The relevance of employer branding in job advertisements for becoming an employer of choice. Journal of Brand Management, 20(05), 355-373.

Fernández-Monroy, M., Martín-Santana, J. D., \& Galván-Sánchez Inmaculada. (2018). Building successful franchise partnerships: The importance of communication and trust. Management Decision, 56(05), 1051-1064. DOI: dx.doi.org.proxy.k.utb.cz/10.1108/MD-07-2016-0528.

Gogolová, M., Poniščiaková, O., \& Ivanková, K. (2015). The Use of External Personnel Marketing in Slovakia. Procedia Economics and Finance, 26(01), 131-138.

Grabara, J. (2013). Employer's expectations towards the employees from the marketing and management department. Polish Journal of Management Studies, 07(01), 58-70.

Hitka, M., Stachová, K., Balážová, Ž., \& Stacho Z. (2015). Differences in Employee Motivation at Slovak Primary Schools in Rural and Urban Areas. International Education Studies, 08(05), 33-42.

Chitu, M. G., Zăgan, R., Firsa, I., Gherasim, A. M., \& Manea, E. (2014). Factors influencing the choice of profession and employment - case study. In 6th International Conference on Education and New Learning Technologies, Edulearn14 Proceedings, 452-460.

Jain, N., \& Bhatt, P. (2015). Employment preferences of job applicants: Unfolding employer branding determinants. Journal of Management Development, 34(06), 634-652. https://doi.org/10.1108/JMD-09-2013-0106.

Jenkins, A. K. (2009). Keeping the talent: understanding the needs of engineering and scientists in the defense acquisition workforce. Defense Acquisition Review Journal, 01(01), 164-170.

Kietzmann, J. H., \& Canhoto, A. (2013). Bittersweet! Understand-ing and managing electronic word of mouth. Journal of Public Affairs, 13(02), 146-159.

Kinkorová, J., \& Topolčan, O. (2012). Overview of healthcare system in the Czech Republic. The EPMA Journal, 03(04).

Love, L. F., \& Singh, P. (2011). Workplace Branding: Leveraging Human Resources Management Practices for Competitive Advantage Through "Best Employer Surveys". Journal of Business and Psychology, 26(02), 175-181.

Mandhanya, Y., \& Maitri, S. (2010). Employer Branding: A Tool for Talent Management. Global Management Review, 04(02), 43-48.

Martin, G., Gollan, P. J., \& Grigg, K. (2011). Is there a bigger and better future for employer branding? Facing up to innovation, corporate reputations and wicked problems in SHRM. The International Journal of Human Resource Management, 22(17), 36183637.

Mihályi, P. (2000). Post-socialist health systems in transition: Czech Republic, Hungary and Poland. Central European University Working Paper, 04(01).

Minchington, B. (2006). Your Employer Brand. Attract, engage, retain. Torrensville: Collective learning Australia, 2006, p. 232.

Ng, E. S. W., Schweitzer, L., \& Lyons, S. T. (2010). New generation, great expectations: A field study of the millennial generation. Journal of Business and Psychology, 25(02), 281292.

Oláh J., Szolnok Á., Nagy G., Lengyel P., Popp J. (2017). The Impact of Lean Thinking on Workforce Motivation: A Success Factor at LEGO Manufacturing Ltd. Journal of Competitiveness, 09(02), 93-109. D0I: doi.org/10.7441/joc.2017.02.07.

Plchová, J., \& Turáková, A. (2016). Employer Branding of The Companies and Its Impact on University Students - Trends Research in Slovakia and China. Marketing Identity, 01/02, 247-256. Retrieved from https://www.ceeol.com/search/articledetail?id=534414. 
Radford, T. (2009). 7 Ways To Sell Your Employer Brand. Dynamic Business. [Online]. https://dynamicbusiness.com.au/topics/news/selling-your-employerbrand3973.html.

Saini, G. K., \& Jawahar, I. M. (2019). The influence of employer rankings, employment experience, and employee characteristics on employer branding as an employer of choice. Career Development International, 24(07), 636-657.

Saini, G. K., Rai, P., \& Chaudhary, M. K. (2014). What do best employer surveys reveal about employer branding and intention to apply? Journal of Brand Management, 21(02), 95-111.

Saxena, P., Jain, R. (2012). Managing career aspirations of generation Y at work place. International Journal of Advanced Research in Computer Science and Software Engineering, 02(07), 114-118.

Sokro, E. (2012). Impact of employer branding on employee attraction and retention. European Journal of Business and Management, 04(18), 164-173.

Strenitzerová, M. (2016). HR Marketing in Terms of HR Managers and Employees Application E-Marketing Tools. Marketing Identity, 01/02, 463-473. Retrieved from https://www.ceeol.com/search/article-detail?id=534470.

Suikkanen, E. (2010). How does Employer Branding increase Employee Retention? Metropolia University of Applied Sciences, Finland.

Sullivan, J. (2004). The Eight Elements of a Successful Employment Brand. Retrieved from http://www.ere.net/2004/02/23/the-8-elements-of-a-successfulemploymentbrand.

Urbancová, H., \& Hudáková, H. (2017). Benefits of Employer Brand and the Supporting Trends. Economics and Sociology, 10(04), 41-50. DOI:10.14254/2071789X.2017/10-4/4.

Verma, D., \& Ahmad, A. (2016). Employer Branding: The Solution to Create Talented Workforce. The IUP Journal of Brand Management, 13(01), 42-56. Retrieved from https://papers.ssrn.com/sol3/papers.cfm?abstract_id=2817822.

Wilden, R. M., Gudergan, S., \& Lings, I. N. (2010). Employer branding: strategic implications for staff recruitment. Journal of Marketing Management, 26(01-02), 56-73.

Woźniak, J. (2015). The Use of Gamification at Different Levels of E-Recruitment. Management Dynamics in the Knowledge Economy, 03(02), 257-278.

Wroblowská, Z. (2019). Personality Requirements for Ukrainian and Czech Managers Creating Brands as a Competitive Advantage. Journal of Competitiveness, 11(01), 152167. DOI: https://doi.org/10.7441/joc.2019.01.10. 